\title{
KOBIETA JAKO POKUSA DLA MNICHA WEDLUG EWAGRIUSZA Z PONTU
}

W celu właściwego zrozumienia opinii i nauczania Ewagriusza na temat kobiet, należy je umieścić w kontekście jego nauki duchowej adresowanej do mnichów, gdyż bez niego jawi się on nam jako zaciekły mizoginista. A kontekst jego nauki duchowej jest następujący: mnich dobrowolnie wybiera anachorezę, czyli oddalenie się od świata na pustyni, by szybciej i skuteczniej

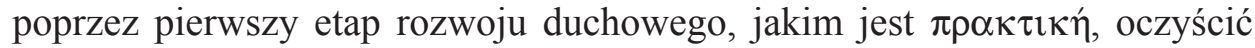
swoją duszę z ośmiu namiętnych myśli, osiągając stan beznamiętności, a następnie doświadczyć duchowego poznania Boga $(\gamma \nu \omega \sigma \tau \imath \kappa \eta ́){ }^{1}$. Odejście na pustynię i walka o oczyszczenie duszy stawiają sobie za cel uwolnienie się nie tylko od spotkań z ludźmi, ale również od wszelkich obrazów tego świata, by móc oglądać Boga: „Nie będziemy przecież mogli oglądać Boga, jeśli wpierw nie usuniemy całkowicie $\mathrm{z}$ naszego myślenia namiętności i obrazów tego świata, pełnych zgorszenia i rozlicznych zasadzek"”. Jeśli więc Pontyjczyk postrzegał spotkanie z kobietami jako pokusę dla mnicha i przeszkodę na drodze oczyszczania swojej duszy i zdobywania duchowej gnozy, to nie dlatego, że ogólnie pogardzał kobietami czy był zaciekłym mizoginista, ale rozpatrywał tę kwestię w perspektywie wzrostu duchowego i właśnie oczyszczania duszy z wszelkich obrazów ${ }^{3}$. Niektórzy badacze pism Ewagriusza i patrologowie zapominają o tym, zarzucając mu niczym nieuzasadnioną niechęć czy wręcz

* Ks. dr hab. Leszek Misiarczyk, prof. UKSW - profesor nadzwyczajny w Instytucie Nauk Historycznych na Wydziale Nauk Historycznych i Społecznych Uniwersytetu Kard. Stefana Wyszyńskiegow Warszawie; e-mail: 1.misiarczyk@uksw.edu.pl.

${ }^{1}$ Por. G. Bunge, Praktike, Physike und Theologike als stufen der Erkenntnis bei Evagrios Pontikos, w: Ab Oriente et Occidente. Gedenkschrift für W. Nyssen, hrsg. M. Schneider - W. Berschin, St. Ottylien 1996, 59-72; L. Nieścior, Praktike jako walka ze złymi myślami w nauce Ewagriusza z Pontu, VoxP 17 (1997) t. 32-33, 105-113; L. Misiarczyk, Osiem logismoi w pismach Ewagriusza z Pontu, Kraków - Tyniec 2007, 117-168.

${ }^{2}$ Por. Evagrius Ponticus, Epistula 13, thum. A. Ziernicki - L. Nieścior: Listy Ewagriusza z Pontu, w: Ewagriusz z Pontu, Pisma ascetyczne, t. 1, ŹM 18, Kraków - Tyniec 1998, 130.

${ }^{3}$ Por. A. Guillaumont, Le gnostique chez Clément d'Alexandrie et chez Évagre le Pontique, w: Alexandria: Hellénisme, judaïsme et christianisme à Alexandrie. Mélanges offerts au P.C. Mondésert, Paris 1987, 195-201; tenże, La vie gnostique selon Évagre le Pontique, „Annuaire du Collège de France" 80 (1979-1980) 467-470; tenże, Les visions mystiques dans le monachisme oriental chrétiens, w: Colloque organisé par le secrétariat d'État à la Culture, Paris 1976, 116-127. 
nienawiść do kobiet. Warto pamiętać, że nasz Autor patrzył na kobiety z perspektywy mnicha i zagrożeń dla niego płynących ze spotkań z nimi, nigdzie zaś w jego tekstach nie znajdziemy rozważań o kobiecie w kontekście antropologicznym, jej naturze, przypadłościach czy słabościach. Po trzecie wreszcie, choć z jednej strony, zapytany przez jednego z braci czy pozwoli, aby matka i siostra spożyły z nim posiłek, gdy uda się do domu, odpowiedział: „Nie jem z kobietami" ", to jednak z drugiej strony w swoich listach np. do Melanii", do diakonisy Sewery ${ }^{6}$ czy w traktacie $A d$ virginem $^{7}$ wyrażał się z ogromnym szacunkiem o kobietach, traktując je na równi z mężczyznami jako zdolne do bardzo głębokiego życia duchowego. Nawet więcej, napisał swój jeden z najtrudniejszych traktatów w formie listu właśnie do Melanii (Epistula ad Melaniam), w którym zawarł wiele elementów swojej nauki duchowej bardzo trudnych nawet dzisiaj do interpretacji. Gdyby więc uznawał kobiety za mniej inteligentne od mężczyzn i niezdolne do przyjęcia nauki duchowej, to nie pisałby takich tekstów do nich. Ewagriusz nie był więc jakimś zapiekłym mizoginista, jakim chciałaby go widzieć część współczesnych badaczy. Z drugiej jednak strony, prawdą jest, że pisząc o kobiecie jako pokusie i zagrożeniu dla czystości mnicha używał niekiedy określeń, które w dzisiejszym kontekście brzmią bardzo negatywnie, ale musimy ciągle pamiętać o kontekście ascetycznym jego wypowiedzi.

Większość wypowiedzi Ewagriusza na temat kobiet znajdziemy w tekstach dotyczących walki mnicha z demonem nieczystości ${ }^{8}$, czyli w rozdziale 4 traktatu $O$ ośmiu duchach zła i w Liście 16. Nie jest ich dużo, co potwierdza, że mnich z Pontu nie miał jakiejś wrogiej obsesji do kobiet i nie atakował ich przy jakiejkolwiek okazji. Wszystkie odnośne fragmenty pojawiają się w kontekście walki duchowej i przedstawiają kobiety bardzo jednostronnie, zawsze

${ }^{4}$ Evagrius Ponticus, Practicus 96, ed. C. i A. Guillaumont, SCh 171, Paris 1971, 702, thum. E. Kędziorek: Ewagriusz z Pontu, O praktyce [ascetycznej], ŹM 18, 228.

${ }^{5}$ Por. tenże, Epistulae 1, 8, 31, 32, 35 i 37. Zachowały się niewielkie fragmenty greckie Listów: ed. C. Guillaumont, Fragments grecs inédits d'Évagre le Pontique, w: J. Dummer, Texte und Textkritik. Eine Aufsatzsammlung, TU 133, Berlin 1987, 209-221; P. Géhin, Nouveaux fragments grecs des Lettres d'Évagre, „Revue d'Histoire des Textes” 24 (1994) 117-147; tenże, Evagriana d'un Manuscript Basilien, „Muséon” 109 (1996) 66-67; wersja syryjska: ed. W. Frankenberg, Evagrius Ponticus, Abhandlungen der königlichen Gesselschaft der Wissenschaften zu Göttingen, Philologischhistorische Klasse, Neue Folge, vol. 1/2, Berlin 1912, 564-611, thum. A. Ziernicki - L. Nieścior: Listy Ewagriusza z Pontu, ŹM 18, 110-200.

${ }^{6}$ Por. tenże, Epistula 20.

${ }^{7}$ Por. tenże, Ad virginem, ed. H. Greßmann, Nonnenspiegel und Mönchspiegel des Evagrios Pontikos, TU 39, Leipzig 1913, 146-151; ed. S. Elm, Evagrius Ponticus' Sententiae ad virginem, DOP 45 (1991) 97-120; thum. M. Grzelak: Ewagriusz z Pontu, Napomnienie dla dziewicy, ŹM 18, 298-306.

${ }^{8}$ Por. P. Payer, The Bridling of Disire: Views of Sex in the Late Middle Ages, Toronto 1993; D. Allen, Ascetic Theology and the Eight Deadly Thoughts, „Evangelical Journal” 13 (1995) 15-21; tenże, Ascetic Theology and Psychology, w: Limning the Psyche, ed. R.C. Roberts - M.R. Talbot, Grand Rapids 1997, 297-316; Misiarczyk, Osiem logismoi w pismach Ewagriusza z Pontu, s. $217-239$. 
jako pokusę i zagrożenie dla czystości mnicha. Ewagriusz nie widział nigdy spotkań mnicha z kobietą jako relacji, które jeśli są czyste, mogą rozwijać obie strony. Wszystkie teksty można podzielić na trzy podstawowe obszary: 1. mnich powinien unikać jakichkolwiek spotkań z kobietami; 2. podczas spotkań przy okazji kierownictwa duchowego zachować bardzo dużą roztropność i jeśli jest młody raczej się tym nie zajmować; 3. jak sobie radzić z obrazami kobiet $\mathrm{w}$ umyśle.

\section{Mnich powinien unikać jakichkolwiek spotkań z kobietami i spo-} glądania na nie. Według Ewagriusza wszelkie myśli namiętne, zwłaszcza te, które rodzą się w pożądliwej części duszy, powstają poprzez pośrednictwo ciała i zmysłów:

„Krzak ciernisty na pustyni wymyka się płomieniowi ognia, a [mąż] powściągliwy, oddzielony od kobiet, nie rozpłomieni się zmysłowością. Jak bowiem wspomnienie ognia nie rozpala ducha, tak i namiętność nie nabiera mocy, kiedy nie ma materii"'"

W przypadku nieczystości ową materią są spotkania z kobietami i patrzenie na nie, a więc rozbudzanie duszy poprzez zmysł wzroku. Pisał więc nasz autor: „olej karmi lampe latarni, a spotkanie z kobietą wznieca ogień rozkoszy”10. Ewagriusz jako doświadczony mnich i kierownik duchowy przestrzegał więc wszystkich mnichów, zwłaszcza młodych, przed tego typu spotkaniami. Jeśli udawali się na pustynię w celu szybkiego oczyszczenia swojej duszy, odcinając wszelkie bodźce zewnętrzne, zwłaszcza seksualne, to powinni starać się tam przebywać, udając się do miasta tylko w bardzo konkretnej potrzebie, natomiast unikać włóczenia się po zabawach ludowych i świętach:

„Spoglądanie na kobietę jest zatrutą strzałą, zraniła duszę [mnicha] i zapuściła truciznę, a im dłużej trwa, tym większe sprawia zatrucie. Kto pragnie ustrzec się przed taką strzała, niech nie udaje się na publiczne zabawy ludowe i niech nie włóczy się w święta, gapiąc się. Lepiej bowiem pozostać w domu i oddać się modlitwie niż sądzić, że się świętuje i wydać się na pastwę wrogów"11.

Zauważmy, że w przytoczonym fragmencie mnich z Pontu tak naprawdę nie opisuje kobiety, ale raczej koncentruje się na postawie mnicha. Nie określa samej kobiety „zatruta strzałą”, ale spoglądanie na nią przez mnicha, czego zdają się nie zauważać znowu niektórzy badacze jego pism, interpretując ten fragment jako dowód jego pogardy wobec kobiet. Tak więc spoglądanie na kobietę jest zatrutą strzała, która rani duszę mnicha i zapuszcza truciznę, a im dłużej ono trwa, tym większe sprawia zatrucie. Warto podkreślić głęboką

\footnotetext{
${ }^{9}$ Evagrius Ponticus, De octo spiritibus malitiae 5, PG 79, 1149D, thum. L. Nieścior: Ewagriusz z Pontu, $O$ ośmiu duchach zła, ŹM 18, 383.

${ }^{10}$ Tamże 4, PG 79, 1148D, ŹM 18, 381.

${ }^{11}$ Tamże, PG 79, 1148D - 1149A, ŹM 18, 381.
} 
intuicję mnicha z Pontu, którą potwierdziła współczesna psychologia, zwracając uwagę, że uporczywe i pożądliwe oglądanie np. obrazów erotycznych wdrukowuje się bardzo silnie w ludzką psychikę i potem bardzo trudno ich się pozbyć. Dalej, musimy mieć ciagle przed oczami Ewagriańską teorię tworzenia się obrazów przedmiotów oglądanych zmysłami w duszy i umyśle człowieka, które potem poruszają duszę, odciągając ją od jej naturalnej walki o cnotę, a umysł od kontemplacji duchowej rzeczywistości świata materialnego i Boga ${ }^{12}$. W tym kontekście myśl Ewagriusza jest jasna: poprzez spoglądanie na kobietę jej obraz pozostaje w umyśle mnicha na długo i zatruwa go niszcząc owoce kontemplacji. Najlepszym lekarstwem, aby ustrzec się przed taką strzałą, jest pozostać w domu, oddając się modlitwie, niż łudzić się, że się świętuje, wydając się na pastwę wrogów, włócząc się po lokalnych publicznych zabawach i świętach. Z tej wzmianki Ewagriusza można wnioskować, że niektórzy mnisi z byle powodu opuszczali swoje miejsce zamieszkiwania i udawali się na publiczne zabawy lub święta. Była to zapewne praktyka społecznie akceptowana i forma kontaktu z okoliczną ludnością ale Pontyjczyk jest jej przeciwny. Mnich z Pontu, zgodnie z przekonaniem wyrażonym w innym miejscu, że trudniej oczyścić duszę już niegdyś oczyszczoną i zranioną, kolejny raz przestrzega przed nieroztropnym wystawianiem się na tego typu pokusy. Odwołuje się tutaj prawdopodobnie do konkretnych przykładów z życia monastycznego, kiedy to niektórzy mnisi, zamiast pozostawać na pustyni i modlić się, pod jakimkolwiek pretekstem włóczyli się po okolicznych wiejskich zabawach i różnych świętach, gapiąc się na kobiety. Przypomina więc im jedną z podstawowych zasad życia monastycznego, jaką była stabilitas loci, która stanowiła podstawę stabilitas mentis. Mnich włóczęga niszczył pokój duszy, hezychię ${ }^{13}$, wprowadzając się w stan niepokoju wywołany patrzeniem na kobiety, a potem ich obrazami, które zalegały w jego duszy przez długi czas ${ }^{14}$. Tego typu świętowanie określał nieroztropnym wystawianiem się na ataki wrogów.

Szczególnie mocno przestrzegał młodych mnichów przed spotkaniami, zwłaszcza z młodymi kobietami:

„Zbliż się raczej do płonącego ognia niż do młodej kobiety, jeśli sam jesteś jeszcze młody. Gdy bowiem przystapisz do ognia, poczujesz ból i szybko odskoczysz, natomiast obezwładniony słowami kobiety, tak łatwo nie odejdziesz. Kwitnie roślina stojąca nad wodą, a namiętność pożądania na spotkaniach z kobietami" ${ }^{15}$.

${ }^{12}$ Por. L. Nieścior, Kategorie myśli w nauce ascetycznej Ewagriusza z Pontu, RH 44 (1996) 203-230.

${ }^{13}$ Por. J.E. Bamberger, Desert Calm: Evagrius Ponticus, the Theologian as a Spiritual Guide, „Cistercian Studies Quarterly” 27 (1992) fasc. 3, 185-198; G. Bunge, ,Priez sans cesse”. Aux origines de la prièere hésychaste, SMon 30 (1988) 7-16.

${ }^{14}$ Por. Nieścior, Kategorie myśli w nauce ascetycznej Ewagriusza z Pontu, s. 203-230.

${ }^{15}$ Evagrius Ponticus, De octo spiritibus malitiae 5, PG 79, 1149C, ŹM 18, 382-383. 
W ostatnim zdaniu powraca do wyrażonej już wcześniej myśli, że namiętność pożądania seksualnego rozbudzana jest u mężczyzn na spotkaniach z kobietami, podobnie jak kwitnie roślina stojąca nad wodą. Spotkania z kobietami są więc dla pożądliwości mnicha tym samym, czym woda dla rośliny. Natomiast w pierwszej części tego fragmentu zachęca młodego mnicha, aby raczej zbliżył się do ognia, bo wtedy z bólu szybko odskoczy, niż do młodej kobiety, gdyż trudno mu będzie od niej odejść, gdy zostanie obezwładniony jej słowami. Pisząc o zbliżeniu Ewagriusz miał tutaj na myśli raczej bliskość w sensie spotkania się z kobietą, a nie relację seksualną, ale i taką bliskość postrzegał jako zagrożenie dla czystości mnicha. Szczególną rolę zdaje się nasz autor przypisywać obezwładniającej mocy kobiecych słów, choć nic nie wspomina, o jakie słowa mogłoby chodzić. Można tylko się domyślać, że zdarzało się, iż młoda kobieta mogła zakochać się w młodym mnichu i wyznać mu miłość lub dać mu do zrozumienia jak bardzo jest dla niej ważny. Takie wyznania trafiały na zwykłą ludzką potrzebę mnicha-mężczyzny czucia się komuś potrzebnym lub udzielania kobiecie wsparcia. Nie wykluczone, że mnich również zakochiwał się w jakiejś pięknej, młodej kobiecie, a gdy to uczucie było wzmacnianie podobnym wyznaniem drugiej strony, bardzo trudno było się oprzeć dalszemu rozwojowi relacji i rozbudzaniu pożądania seksualnego. W każdym razie powyższy fragment jest pierwszym z tej grupy tekstów, w której Ewagriusz wyraża się o obezwładniającej mężczyzn mocy kobiecych słów.

W tym samym traktacie $O$ ośmiu duchach zła bardzo wyraźnie podkreślał, że podczas spotkania z kobietą to właśnie jej kształty fizyczne mają największy wpływ na mnicha i rozbudzają jego pożądanie:

„Statek miotany przez burzę spieszy do portu, a dusza powściagliwa szuka odosobnienia. Pierwszy bowiem ucieka od fal morskich, które niosą zagrożenie, druga natomiast unika kształtów kobiecych, które przynoszą bolesną zgubę. Bo pięknie przyozdobiony kształt zatapia bardziej niż fala. Od tej bowiem można ujść, płynąc dzięki woli życia, natomiast gdy zwiódł [kogoś] kształt kobiety, [to] skłania [go], aby gardzić nawet własnym życiem"16.

Dusza powściągliwa, jaką powinna być dusza mnicha, szuka odosobnienia od bodźców zewnętrznych, zwłaszcza spoglądania na kształty kobiece. Zdaniem Ewagriusza, przyozdobiony kształt kobiecego ciała jest większym zagrożeniem dla mnicha niż fale dla statku, gdyż zatapia bardziej niż fale. Dlaczego? Dlatego, że - jego zdaniem - od fal można uciec płynąc siłą woli i znajdując motywację w chęci uratowania własnego życia. Natomiast ktoś zwiedziony kształtem kobiety skłonny jest gardzić nawet własnym życiem. Łatwo dostrzec w tym tekście wyraźne przeciwstawienie sobie woli życia człowieka w przypadku zagrożenia na morzu falami i pogardy własnego życia czy wręcz braku woli życia w przypadku rozpalenia pożądliwości kształtami kobiecego ciała. Ewagriusz ma tutaj zapewne na myśli sytuację, kiedy to mnich czy jakiś

\footnotetext{
${ }^{16}$ Tamże, PG 79, 1149C-D, ŹM 18, 383.
} 
inny mężczyzna rozpalony pożądliwością gotów jest ryzykować nawet własne życie, aby tylko zdobyć przedmiot swojego pożądania. Historia ludzkości potwierdza tego typu zachowania ludzi, którzy z powodu niemożności bycia z ukochanym czy ukochana popełniali wręcz samobójstwa. Znowu jednak, co trzeba bardzo mocno podkreślić, nie ma w tym fragmencie jakichkolwiek negatywnych stwierdzeń na temat kobiet, a Ewagriusz przedstawia całą problematykę z perspektywy życia mnicha.

Nasz autor, będąc doskonałym znawcą życia monastycznego, które przecież sam przez wiele lat praktykował, wiedział doskonale, że mnich niekiedy spotyka się przypadkowo z kobietami lub w celach duchowych i dopuszczał taką możliwość. Drugi przypadek zostanie omówiony w dalszej części, tutaj natomiast zatrzymajmy się przy sytuacji przypadkowych spotkań mnicha z kobietami. Jeśli mają one miejsce, nie są niczym nagannym, a Ewagriusz zachęca jedynie mnichów do prawości w myśleniu i pragnieniach, aby te rzekomo ,przypadkowe” spotkania nie były tak naprawdę poszukiwanymi i dyskretnie aranżowanymi przez mnicha. Pisał o tym w Liście 13:

„A również demon nierządu obserwuje przedmiot trosk mnicha, czy, jeśli spotka kobietę, spotyka ją niejako przypadkowo, czy też tak to z góry zaplanował, że ją spotka pod pewnym pretekstem. Bada on także słowa, które mnich wypowiada, czy pobudzają do śmiechu, czy też zachowują wzgląd na skromność. Obserwuje zaś także oczy mnicha, czy może są bezwstydne, i jego chód, czy może jest zmanierowany i czy przez jego zniewieściałą opieszałość nie ujawnia się przypadkiem jakaś namiętność. Bada też jego ubiór, czy jest znoszony, czy też ładny ze względu na jakąś kobietę"17.

Łatwo zauważyć, że, gdy tylko mnich dopuścił do swej duszy pragnienie spotkania kobiety, szybko stawał się ofiarą demona nieczystości. Nie chodziło więc tylko o grzech czynem, ale w myślach. Przyczyną zaś tego wszystkiego była dwoistość pragnień mnicha: z jednej bowiem strony anachoreta udawał się na pustynię, by dążyć do zdobycia cnoty czystości, unikając spotkań z kobietami, jednak pod pozorem koniecznych spotkań z ludźmi pragnął spotykać się również z nimi. Chciał więc z jednej strony osiagnąć czystość i jednocześnie spotkać się z kobietami, co rozbudzało jego pożądliwość. To rozdwojenie pragnień ujawniało się w zewnętrznych postawach mnicha, które demon nieczystości pilnie obserwował i sprytnie wykorzystywał przeciwko niemu. Obserwuje więc, o co tak naprawdę mnich troszczy się w swoim życiu, a prawdziwe jego pragnienia objawiają czyny i słowa. Czy spotyka jakąś kobietę rzeczywiście przypadkowo czy też chciał się z nią spotkać za wszelką cenę i jedynie szukał pretekstu, by przed samym sobą i innymi nie przyznać się do pragnienia jej spotkania? Dalej, demon ten bada słowa anachorety podczas spotkania z kobietą: czy prowokują one do śmiechu, by zachęcić kobietę do dłuższego pozostania z nim czy też są skromne i ograniczają się tylko do

${ }^{17}$ Tenże, Epistula 16, 3, ŹM 18, 132-133. 
tego, co konieczne? Następnie obserwuje oczy mnicha czy patrzy on na ciało kobiety czy nie, a jeśli na nią, to czy w jego spojrzeniu widać pożądanie czy nie. Innymi elementami, które ukazują namiętność mnicha są jego „zmanierowany chód” lub „zniewieściała opieszałość”. Ewagriusz nie wyjaśnia bliżej, co rozumie pod tymi pojęciami, skazani więc jesteśmy na domysły. Chodzi zapewne o taki sposób chodzenia, który pokazuje zabiegi mnicha o względy kobiety, czyniąc go jednocześnie mniej stanowczym w kończeniu spotkania. Demon ten bada wreszcie czy mnich jest ubrany w swój stary, znoszony ubiór używany na pustyni czy też na spotkanie z kobietą ubrał się w nowy, ładny strój. Elementem kluczowym tej pokusy, jak widzieliśmy, jest dwoistość pragnień mnicha: z jednej strony pragnienia życia monastycznego w czystości i oczyszczenie swojej duszy z wszelkich namiętnych pragnień; z drugiej zaś - ludzka potrzeba kontaktów z kobietami. Lekarstwem, jak podpowiada Ewagriusz, będzie spójność pragnień i ich zgodność z postawami zewnętrznymi, tzn. pragnienie cnoty czystości i pokazanie tego w konkretnych postawach. Skoro mnich zdecydował się na anachorezę, to oznacza, że rzeczywiście chce wyzwolić się od wpływu wszelkich bodźców zewnętrznych, w tym wypadku również oglądania kobiet.

Ewagriusz radzi wykorzystać wszelkie spotkania z kobietami do chwalenia Boga i okazję do duchowego wzrostu. Pisał: „Widok kobiety pobudza zmysłowego do przyjemności, powściagliwego zaś skłania do chwalenia Bo$\mathrm{ga}{ }^{\prime 18}$. Problem nie leży więc po stronie kobiety, ale mnicha. Jeśli nie oczyścił on jeszcze wystarczająco pożądliwej części swojej duszy i jest nadal zmysłowy, wtedy widok kobiety rozbudzi jego pożądliwość, natomiast jeśli jest już wystarczająco powściągliwy, wtedy widok pięknej kobiety pobudzi go do chwalenia Boga za piękno kobiet i ludzkiego ciała. Znowu widzimy, że nie postrzegał on negatywnie kobiet, ale wszelkie swoje zachęty kierował tylko do mnichów. Zdaniem bowiem Ewagriusza każde spotkanie może być dobrą okazją do chwalenia Boga, a każdy widok kobiety czy nawet pokusa, jeśli zostanie umiejętnie i mądrze przeżyta, może stać się dobrą okazją do duchowego wzrostu. Przestrzega jednak jednocześnie, aby nie ufać sobie nawet wtedy, gdy wydaje się, że podczas spotkań z kobietami namiętność jest wyciszona:

„Gdyby namiętność była uciszona podczas spotkań z kobietami, nie ufaj jej, nawet wtedy gdy obiecuje beznamiętność. Bowiem także i pies łasi się oddzielony od sfory, kiedy jednak wyjdzie na zewnątrz, pokazuje swoją złość"19.

Może się zdarzyć, że mnich przez długie lata pobytu na pustyni i walkę duchową tak oczyści swoją duszę, że bliski będzie bram beznamiętności i namiętność pozostanie uciszona podczas spotkań z kobietami, ale nawet wtedy Pontyjczyk radzi, aby nie dowierzać sobie. Widzimy więc, że przemawia tutaj z ogromnym realizmem jako rzeczywiście doświadczony kierownik duchowy.

${ }^{18}$ Tenże, De octo spiritibus malitiae 6, PG 79, 1149D - 1152A, ŹM 18, 384.

${ }^{19}$ Tamże, PG 79, 1152A, ŹM 18, 384. 
Zdarzały się bowiem również w jego czasach przypadki, że nawet u utwierdzonych we wstrzemięźliwości mnichów po spotkaniach z kobietami rozbudzała się pożądliwość i popychała ich niekiedy nawet do grzechów nieczystych.

2. Zachowania uwodzicielskie kobiet podczas spotkań duchowych. Nawet mnich, który wybrał anachorezę, przebywał na pustyni i gorliwie troszczył się o zachowanie czystości, był niekiedy wystawiany na spotkania z kobietami przy okazji kierownictwa duchowego. Ewagriusz zachęca mnichów, aby te spotkania rzeczywiście były poświęcone rozwojowi duchowemu i jednocześnie przestrzega przed uwodzicielskimi zachowaniami kobiet podczas nich. Oto interesujący nas fragment z traktatu De octo spiritibus malitiae:

„Uciekaj od spotkań z kobietami, jeśli chcesz być roztropny i nie dawaj im nigdy swobody, by nie okazały wobec ciebie zuchwałości. Na początku bowiem zachowują lub udają obłudny szacunek, potem jednak ośmielają się bezwstydnie na wszystko. Na pierwszym spotkaniu mają wzrok spuszczony, mówią łagodnie i płaczą wzbudzając współczucie, zachowują się dostojnie i wzdychają gorzko, pytają na temat czystości i słuchają pilnie [odpowiedzi]. Widzisz je po raz drugi - podniosły już głowę nieco wyżej, za trzecim razem zbliżają się bezczelnie. Uśmiechnąłeś się - tamte wybuchły gromkim śmiechem. Następnie ozdabiają się i pokazują się tobie ostentacyjnie, dobierają spojrzenia radośnie, zwiastując namiętność, podnoszą brwi i obracają powiekami, obnażają szyję i ramię i grają pieszczotliwie całym ciałem, mówią słowa, które czynią [cię] miękkim wobec namiętności, a silą się na takie brzmienie [głosu], które urzeka słuch, aż całkiem osaczą [twoja] duszę. To staje się dla ciebie haczykiem wabiącym ku śmierci i siecią zręcznie spleciona, który ciągnie ku zgubie. Niech cię [kobiety] nie zwiodą słowami, gdy przytulają się łagodnie do ciała, bowiem ukrywa się w nich zły jad dzikich zwierząt"20.

Ewagriusz jawi się nam w tym tekście jako doskonały znawca nie tylko duszy mnicha mężczyzny, ale również psychiki kobiecej. Choć pada tutaj dosyć dużo różnych negatywnych określeń na temat kobiet, to jednak nie jest to próba demonizowania kobiet jako takich, ale trzeźwy realizm życia, który podpowiada, że nawet spotkania rzekomo duchowe mnicha z kobietami stanowią często zagrożenie dla jego czystości. Ewagriusz zachęca anachoretów, by unikali jakichkolwiek spotkań z kobietami, gdyż bardzo szybko spotkania niby duchowe z powodu świadomego lub nieświadomego uwodzicielskiego zachowania kobiety i pożądania mnicha przeradzały się w kuszenie. Nasz autor wręcz po mistrzowsku portretuje kolejne etapy coraz większej zuchwałości kobiety wobec mnicha. Na pierwszym spotkaniu mają opuszczony wzrok i wcale nie patrzą na anachoretę, mówią spokojnie i łagodnie, starając się płaczem wzbudzić współczucie i litość, bądź też przyjmują dostojną postawę i gorzko wzdychają nad swoim losem. Takie zachowania nazwalibyśmy dzisiaj „nieświadomą manipulacją”, gdy

${ }^{20}$ Tamże 4, PG 79, 1149A-B, ŹM 18, 381-382. 
kobieta ma opuszczone oczy, pokazując, że wcale jej nie zależy na spoglądaniu na mnicha, ale tylko na sprawach duchowych. Poprzez spokojne i łagodne mówienie lub dostojną postawę i gorzkie wzdychanie nad swoim losem starają się wzbudzić litość i współczucie w mnichu dla swojej trudnej sytuacji życiowej. Szybko jednak przenoszą akcent rozmowy ze swojej niby trudnej sytuacji na życie mnicha. Wykazują zainteresowanie tematyką czystości i wiele o to pytają. Według Pontyjczyka to właśnie chęć wzbudzenia litości czy współczucia oraz wykazanie zainteresowania stylem życia, a konkretnie czystością mnicha, rozmiękczają jego duszę. Któż nie chciałby pomóc i pocieszyć osoby płaczącej albo jaki celibatariusz nie poczułby wewnętrznej satysfakcji, gdy jakaś kobieta interesuje się trudami jego ascezy, podziwiając zwłaszcza jego wstrzemięźliwość seksualną? Rodzi się wtedy w jego sercu subtelna próżność i wzmacnia się pragnienie bycia komuś potrzebnym: ktoś potrzebuje jego duchowej pomocy i docenia jego życie w czystości. Na drugim spotkaniu kobieta jest już śmielsza i podnosi głowę nieco wyżej, a na trzecim zbliża się do mnicha. Następnie na jego delikatny uśmiech odpowiada wybuchem śmiechu, potem na kolejne spotkania przychodzi ubierając się w różne ozdoby, podnosi brwi i przewraca oczami, wreszcie obnaża szyję i ramiona, ruchami ciała, słowami i brzemieniem głosu osacza jego duszę, by ostatecznie przytulić się łagodnie do jego ciała. Dotyk ciała dopełniał dzieła rozbudzenia pożądliwości mnicha. Nie przekonuje interpretacja tego fragmentu w kluczu mizoginistycznym, gdyż opis jest tak bardzo realistyczny, iż prawdopodobnie Ewagriusz sam osobiście doświadczył takiego zachowania jakiejś kobiety, która szukała u niego porady duchowej albo też dostrzegał ją w życiu tych anachoretów, którzy zwracali się do niego o pomoc $w$ rozeznaniu natury takich spotkań bądź też już sami padli ich ofiarą ${ }^{21}$. Asceta z Pontu radził więc, aby kierownictwem duchowym kobiet, zwłaszcza młodych, zajmowali się raczej starsi wiekiem i duchowo bardziej doświadczeni anachoreci niż młodzi adepci życia monastycznego.

3. Obrazy kobiet w umyśle. W kontekście całej nauki duchowej mnicha z Pontu warto zatrzymać się na chwilę nad jeszcze jednym aspektem jego prezentacji kobiet, a mianowicie obrazach kobiet w umyśle mnicha. Niekiedy nawet gdy mnich nie spotyka się z kobietami, ale jego dusza nie jest do końca oczyszczona, w jego umyśle pozostają obrazy poprzednich spotkań. Według Ewagriusza, jeśli wspomnienie kobiety nie wzbudza już namiętności albo wręcz pobudza do modlitwy i kontemplacji Boga, to oznacza, że mnich rzeczywiście osiagnął wyżyny wstrzemięźliwości i cnoty:

„Gdy wspomnienie kobiety pojawia się beznamiętnie, a myśl o niej nie wzbudza namiętności, wtedy możesz sądzić, że wspiąłeś się na wyżyny powścią-

${ }^{21}$ Por. J.T. Linhard, On „Discernment of Spirits” in the Early Church, ThS 41 (1980) 502-529; L. Nieścior, Rozeznawanie myśli i spór z nimi wedtug Ewagriusza z Pontu, w: Droga doskonalenia chrześcijańskiego w epoce patrystycznej, red. F. Drączkowski - J. Pałucki - M. Szram, Lublin 1997, $31-56$. 
gliwości. Jeśli zaś jej [duchowy] obraz pobudza cię do kontemplacji i jesteś w stanie porównać jej członki do mocy duszy, wtedy bądź pewny, że znajdujesz się w stanie cnoty. Ale nawet wtedy nie zatrzymuj się przy tego rodzaju myślach ani nie obcuj dłużej w duchu z kształtem kobiety, bowiem namiętność chętnie wraca i niesie ze sobą niebezpieczeństwo. Jak bowiem odpowiednio długie topienie oczyszcza srebro, a zbyt długie łatwo może je zepsuć, tak utrzymywane wyobrażenie kobiety niszczy stan powściagliwości. Nie poddawaj swego umysłu wyobrażeniu kobiety ani nie zajmuj się dłużej ukazującym się obliczem, aby nie zapaliło w tobie płomienia rozkoszy i nie spaliło «klepiska» twej duszy. Jak bowiem iskra przebywając w plewach wznieca płomień, tak wspomnienie kobiety dłużej trwające rozpala pożądliwość"22.

Widzimy, że Ewagriusz podaje dwa podstawowe kryteria pomocne w ocenie stanu własnej duszy. Pierwsze to stan, gdy wspomnienia kobiety nie wzbudzają namiętności w mnichu, co oznacza, iż osiągnął on wyżyny powściągliwości. Drugi natomiast, wyższy stan ma miejsce wtedy, gdy obraz kobiety w umyśle pobudza mnicha do kontemplacji świata stworzonego i Boga jako Stworzyciela. Pontyjczyk pisał tutaj o sytuacji, gdy mnich jest w stanie porównać członki jej ciała do mocy duszy, czyli do rozumowania, myślenia, oglądania, wyjaśniania, wyobrażania i przypominania, jak dopowiada w Scholia in Psalmos ${ }^{23}$. Wtedy, jego zdaniem, mnich znajduje się rzeczywiście w stanie cnoty. Nawet jednak w takim stanie zachęca anachoretów, aby nie zatrzymywali się przy takich myślach, ani nie obcowali w duchu z kształtem kobiety, gdyż również wyobrażenia niszczą stan wstrzemięźliwości i rozpalają płomienie pożądliwości. Ostatnia więc sytuacji dotyczy nie tyle bezpośrednich spotkań z kobietami albo patrzenia na nie, ile raczej ich obrazu w duszy mnicha. Obraz ten był pozostałością z poprzednich spotkań lub wyrazem fantazji mnicha i pojawiał się na jawie albo podczas snu ${ }^{24}$. Nie jest oczywiście żadną winą kobiety, jeśli jej obraz pozostaje w umyśle mnicha, ale jego samego. Jak wiemy, Ewagriusz pisząc o oczyszczeniu duszy miał na myśli nie tylko ograniczenie oddziaływania aktualnych bodźców na wyobraźnię mnicha, ale również oczyszczenie duszy z wszelkich obrazów, które w niej nadal pozostają. Była to więc zachęta do ogromnej pracy duchowej nad własną wyobraźnią i myślami.

${ }^{22}$ Evagrius Ponticus, De octo spiritibus malitiae 6, PG 79, 1152A-B, ŹM 18, 384.

${ }^{23}$ Por. tenże, Scholia in Psalmos 102, 1.

${ }^{24}$ Por. A. Refoulé, Rêves et vie spirituelle d'après Évagre le Pontique, VS 56 (1961) 470-516; L. Misiarczyk, Diagnostyczna wartość snów w procesie duchowego rozeznawania wedtug Ewagriusza z Pontu, StPł 34 (2006) 121-138. 


\section{WOMAN AS A TEMPTATION FOR A MONK ACCORDING TO EVAGRIUS OF PONTUS}

\section{(Summary)}

The article presents the teaching of Evagrius of Pontus on women. The author stresses the need to embed evagrian reflection in the context of strict monastic life and asceticism without which a monk of Pontus appears as mizoginist. Evagrius in his texts on women teaches anchorites three things. Firstly, it reminds them that they have chosen the life in the desert and should avoid any encounters with women. They have to stay rather in their cells praying instead of participating the local feasts and games. Secondly, it encourages that during the meetings on the occasion of spiritual direction monks should be extremely prudent and that this task is more proper to the senior monks. Thirdly, it teaches how to cleanse the soul and mind from the images of women.

Key words: Evagrius of Pontus, asceticism, monasticism, women.

Słowa kluczowe: Ewagriusz z Pontu, asceza, monastycyzm, kobiety.

\section{BIBLIOGRAFIA}

\section{Źródła}

Evagrius Ponticus, Ad virginem, ed. H. Greßmann, Nonnenspiegel und Mönchspiegel des Evagrios Pontikos, TU 39, Leipzig 1913, 146-151; G. Bunge, Origenismus-Gnostizismus: Zum geistesgeschichtlichen Standort des Evagrios Pontikos, VigCh 40 (1986) 32-38; S. Elm, Evagrius Ponticus' Sententiae ad Virginem, DOP 45 (1991) 97-120, thum. M. Grzelak: Ewagriusz z Pontu, Napomnienie dla dziewicy, w: Ewagriusz z Pontu, Pisma ascetyczne, t. 1, ŹM 18, Kraków - Tyniec 1998, 298-306.

Evagrius Ponticus, De octo spiritibus malitiae, PG 79, 1145A - 1164D, tłum. L. Nieścior, Ewagriusz z Pontu, $O$ ośmiu duchach zła, w: Ewagriusz z Pontu, Pisma ascetyczne, t. 1, ŹM 18, Kraków - Tyniec 1998, 373-403 (ta sama wersja została przedrukowana w: Ewagriusz z Pontu, O różnych rodzajach złych myśli. O ośmiu duchach zła, BOK 26, Kraków 2006, 54-84).

Evagrius Ponticus, Epistulae LXII, fragmenty greckie: ed. C. Guillaumont, Fragments grecs inédits d'Évagre le Pontique, w: J. Dummer, Texte und Textkritik. Eine Aufsatzsammlung, TU 133, Berlin 1987, 209-221; P. Géhin, Nouveaux fragments grecs des Lettres d'Évagre, „Revue d'Histoire des Textes” 24 (1994) 117-147; tenże, Evagriana d'un Manuscript Basilien, „Muséon” 109 (1996) 66-67; wersja syryjska: ed. W. Frankenberg, Evagrius Ponticus, Abhandlungen der königlichen Gesselschaft der Wissenschaften zu Göttingen, Philologisch-historische Klasse, Neue Folge, vol. 1/2, Berlin 1912, 564-611. tłum. A. Ziernicki - L. Nieścior: Listy Ewagriusza z Pontu, w: Ewagriusz z Pontu, Pisma ascetyczne, t. 1, ŹM 18, Kraków - Tyniec 1998, 110-200.

Evagrius Ponticus, Practicus, ed. C. i A. Guillaumont, Évagre le Pontique. „, Traité pratique ou le Moine”, t. 1-2, SCh 170-171, Paris 1971, thum. E. Kędziorek: Ewagriusz z Pontu, O praktyce [ascetycznej], w: Ewagriusz z Pontu, Pisma ascetyczne, t. 1, ŹM 18, Kraków - Tyniec 1998, 201-230. 


\section{Opracowania}

Allen D., Ascetic Theology and the Eight Deadly Thoughts, „Evangelical Journal” 13 (1995) 15-21.

Allen D., Ascetic Theology and Psychology, w: Limning the Psyche, ed. R.C. Roberts M.R. Talbot, Grand Rapids 1997, 297-316.

Bamberger, Desert Calm: Evagrius Ponticus, the Theologian as a Spiritual Guide, „Cistercian Studies Quarterly" 27 (1992) fasc. 3, 185-198.

Bunge G., ,, Priez sans cesse”. Aux origines de la prière hésychaste, SMon 30 (1988) 7-16.

Bunge G., Praktike, Physike und Theologike als stufen der Erkenntnis bei Evagrios Pontikos, w: Ab Oriente et Occidente. Gedenkschrift für W. Nyssen, hrsg. M. Schneider - W. Berschin, St. Ottylien 1996, 59-72.

Guillaumont A., Le gnostique chez Clément d'Alexandrie et chez Évagre le Pontique, w: Alexandria: Hellénisme, judaïsme et christianisme à Alexandrie. Mélanges offerts au P.C. Mondésert, Paris 1987, 195-201.

Guillaumont A., La vie gnostique selon Évagre le Pontique, „Annuaire du Collège de France" 80 (1979-1980) 467-470.

Guillaumont A., Les visions mystiques dans le monachisme oriental chrétiens, w: Colloque organisé par le secrétariat d'État à la Culture, Paris 1976, 116-127.

Linhard J.T., On „Discernment of Spirits” in the Early Church, ThS 41 (1980) 502-529.

MisiarczyK L., Diagnostyczna wartość snów w procesie duchowego rozeznawania wedtug Ewagriusza z Pontu, StPł 34 (2006) 121-138.

Misiarczyk L., Osiem logismoi w pismach Ewagriusza z Pontu, Kraków - Tyniec 2007.

Nié́CIOR L., Kategorie myśli w nauce ascetycznej Ewagriusza z Pontu, RH 44 (1996) 203-230.

NieŚCIOR L., Rozeznawanie myśli i spór z nimi wedtug Ewagriusza z Pontu, w: Droga doskonalenia chrześcijańskiego w epoce patrystycznej, red. F. Drączkowski - J. Pałucki - M. Szram, Lublin 1997, 31-56.

Nieścior L., Praktike jako walka ze złymi myślami w nauce Ewagriusza z Pontu, VoxP 17 (1997) t. 32-33, 105-113.

PAyer P., The Bridling of Disire: Views of Sex in the Late Middle Ages, Toronto 1993.

Refoulé A., Rêves et vie spirituelle d'après Évagre le Pontique, VS 56 (1961) 470-516. 